\title{
Hakikat Fitrah Manusia dan Pendidikan Anak dalam Pandangan Islam (Suatu Tinjauan Teoritis)
}

\author{
Agus Riyan Oktori \\ Institut Agama Islam Negeri Curup \\ agusriyanoktori@,iaincurup.ac.id
}

\begin{abstract}
Children's education should be based on what is called buman nature, because every cbild who is born has a natural disposition. The environment that exists in educational institutions and the community around the place of residence has a very important role in the effort to develop this nature. Education based on the concept of humanizing humans should be able to develop this potential or nature. In this paper, we will try to examine the nature of buman nature and how to educate children when referring to the Islamic view by using library research or library research. The common thread in this paper is that each student has quite a variety of potential, this potential should have a place or container so that it can be maximized. The development of this potential is none other than through a process called education. Education should not always ground students who have only cognitive abilities, there are many special things related to the potential of students who can be developed through the educational process.
\end{abstract}

Keywords: Human Nature, Children Education

\begin{abstract}
Abstrak: Sudah seharusnya pendidikan anak harus berlandaskan kepada yang namanya fitrah manusia, karena setiap anak yang terlahir telah memiliki firah. Lingkungan yang ada dalam lembaga pendidikan serta masyarakat sekitar tempat tinggal mendapatkan perannya yang begitu penting dalam upaya pengembangan fitrah tersebut. Pendidikan yang berlandaskan pada konsep memanusiakan manusia, sudah sepatutnya mampu mengembangkan potensi atau fitrah tersebut. Pada tulisan ini akan coba mengkaji terkait hakikat fitrah manusia dan bagaiman pendidikan anak apabila merujuk pada pandangan Islam dengan menggunakan penelitian studi pustaka atau penelitian Library Research. Adapun benang merah dalam tulisan ini adalah bahwa setiap peserta didik itu memiliki potensi yang cukup beragam, sudah seharusnya potensi tersebut harus mendapatkan tempat atau wadah agar bisa dimaksimalkan. Pengembangan potensi tersebut tidak lain melalui suatu proses yang dinamakan pendidikan. Pendidikan seyogyanya tidak harus selalu membumikan peserta didik yang memiliki kemampuan kognitif saja, banyak hal istimewa terkait potensi peserta didik yang mampu dikembangkan melalui proses pendidikan.
\end{abstract}

Kata Kunci: Fitrah Manusia, Pendidikan Anak

AR-RIAYAH : Jurnal Pendidikan Dasar vol. 5, no. 2, 2021

IAIN Curup - Bengkulu 1 p ISSN 2580-362X; e ISSN 2580-3611

http://journal.iaincurup.ac.id/index.php/JPD

DOI: $10.29240 /$ jpd.v5i2.3506 


\section{PENDAHULUAN}

Allah tidak menciptakan manusia dan menempatkannya di muka bumi hanya sebagai boneka bisu yang tidak melakukan aktifitas, tidak menjalankan kehidupan sosial bermasyarakat, bahkan hanya duduk manis menunggu tanpa ada perintah yang harus di kerjakan. ada tugas yang sudah harus dijalankan oleh manusia selama proses perjalanan hidupnya di dunia. yakni menjadi pemakmur bumi yang menjalankan perintah-Nya dan menjauhi larangan-Nya. Tugas yang juga tidak kalah penting selama di bumi adalah menjaga, mengelola, serta memanfaatkan kekayaan alam yang ada untuk dapat menjadi sumber penghidupan sebagai upaya memenuhi kebutuhan dan kesejahteraan manusia itu sendiri. Alqur'an tidak melihat manusia hanya sebagai makhluk yang di ciptakan tanpa unsur kesengajaan, melainkan manusia diciptakan berdasarkan skenario Allah agar mampu mengemban tugas sebagai pemimpin di bumi. Manusia telah Allah berikan kemampuan serta kekuatan positif agar mampu memberikan perubahan terhadap proses kehidupan di dunia menuju suatu hal yang lebih baik. ${ }^{1}$

Alqur'an dengan begitu terperinci menyampaikan bagaimana proses perjalanan dan keberadaan manusia sebagai makhluk hidup. Manusia di bekali dengan beragam kemampuan dan kecerdasan yang begitu jauh apabila dibandingkan dengan makhluk lainnya. Penjabaran tersebut dapat kita lihat dalam Alqur'an surat An-Nahl ayat 78 :

1 M Quraish Shihab memberikan suatu definisi dari Khalifah, pertama adalah seseorang yang memperoleh keperayaan untuk memimpin maupun mengelola suatu tempat yang besar maupun kecil, serta yang kedua khalifatullan memiliki kemampuan untuk menjalankan tanggung jawabnya, sekalipun dapat melakukan suatu kesalahan maupun kehilafan. Mengemban tugas sebagai seorang khalifatullah sangatlah luar biasa, namun tugas tersebut mampu memperlihatkan jalan dan fungsi dari manusia sebagai makhluk ciptaan Allah dengan amanah sebagai khalifah berdasarkan tuntunan dari Allah. Perintahnya sebagai seorang khalifah tidak hanya sebatas mengelola alam semesta, akan tetapi Allah telah memberi manusia kemampuan, kecerdasan, serta berakal sebagai pengantar untuk memahami ilmu pengetahuan. Lihat Mualimin, Konsep Fitrah Manusia dan Implikasinya dalam Pendidikan Islam, At-Tadzkiyah: Jurnal Pendidikan Islam Volume 8 No 2 Tahun 2017, 256 


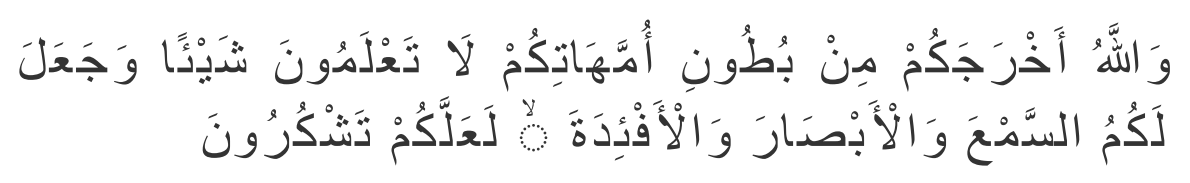

Dan Allah mengeluarkan kamu dari perut ibumu dalam keadaan tidak mengetahui sesuatupun, dan Dia memberi kamu pendengaran, penglihatan dan hati, agar kamu bersyukur

Manusia juga merupakan makhluk yang memiliki beragam dimensi. Memahami manusia yang hanya pada satu sudut pandang hanya akan menemukan pemahaman yang bersifat stagnan pada manusia itu sendiri. Hakikat dari manusia tidak bisa didapatkan secara kompleks, setiap kali seseorang merasa telah menyelesaikan pemahamannya terhadap manusia, akan muncul lagi interpretasi terhadap manusia yang belum di pahami. Manusia merupakan makhluk yang penuh dengan sesuatu yang misterius, hal tersebut dikarenakan keterpisahan manusia dengan dirinya justru bertolak belakang dengan keinginannya yang begitu kuat untuk mengetahui dunia yang ada di luar dari dirinya. ${ }^{2}$

Sehubungan dengan penciptaan manusia serta potensi-potensi yang telah Allah berikan padanya, akan memiliki keterkaitan dengan konsep fitrah manusia. Karena konsep fitrah sendiri merupakan kemampuan yang Allah berikan pada manusia untuk digunakan selama proses kehidupannya di bumi. Fitrah juga dapat diartikan sebagai suatu keadaan dari penciptaan manusia yang memiliki kecendrungan dalam menerima suatu kebenaran. Fitrah juga di artikan sebagai kemampuan yang diberikan Allah kepada manusia, tertanam pada diri manusia, serta

2 Abuddin Nata, Filsafat Pendidikan Islam, Jakarta: Logos Wacana Ilmu, 1997, hlm. 26. Lihat juga Lukis Alam, Perspektif Pendidikan Islam Mengenai Fitrah Manusia, Jurnal Tarbawi Volume 1 No. 2 Tabun 2015, hlm. 42. Konsep manusia menurut sudut pandang tertentu merupakan hal yang penting. Konsep tersebut dirasakan penting karena ia termasuk pandangan manusiawi yang senantiasa dicari, yakni suatu pandangan makhluk unik yang sejak kehadirannya di muka bumi hakekatnya tidak pernah di mengerti dengan tuntas. Lihat Muhammad Yasir Nasution, Manusia Menurut Al-Ghazali, Jakarta: Rajawali Press, 1988, 1 
bersemayam dalam kehidupan manusia yang bertujuan agar mampu mengenal Allah (ma'rifatullah). ${ }^{3}$

Secara etimologi, asal kata fitrah berasal dari bahasa arab, yakni fathara yang artinya belah atau pecah. Fitrah juga diartikan sebagai kejadian (al-ibitida) muncul (thulu), serta penciptaan (khalqun). Sedangkan menurut terminologi fitrah diartikan sebagai mengadakan sesuatu yang relevan dengan kondisi, serta dipersiapkan untuk menjalankan perilaku tertentu. Fitrah juga diartikan sebagai potensi dasar yang dimiliki manusia dan itu di bawa sejak lahir dan memiliki komponen psikologi yang memiliki keterikatan. Apabila coba dihubungkan dengan manusia, fitra memiliki makna yakni Tuhan menempatkan manusia di bumi dengan kemampuan yang beragam, semua itu telah di miliki sejak manusia itu terlahir di bumi. ${ }^{4}$

Anak ${ }^{5}$ adalah hadiah istimewa dari Allah untuk setiap pasangan yang sedang tinggal sementara di bumi. Suatu kebahagiaan yang tak ternilai meskipun dengan materi berlimpah sekalipun. Tiba pada fase di mana pasangan telah memiliki keturunan, saat itu juga amanah untuk memberikan pengasuhan, pengarahan, bimbingan, serta mengenyam pendidikan yang sesuai sedari dia anak-anak sampai ke tahap dewasa. Pendidikan yang dimaksud bukan hanya sekedar menyiapkan fasilitas

3 Toni Pransiskan, Konsepsi Fitrah Manusia dalam Perspektif Islam dan Implikasinya dalam Pendidikan Islam Kontemporer, Jurnal Ilmiah DIDAKTIKA Volume 17 No 1 Tabun 2016, 2

4 Aas Siti Solichah, Konsepsi Pendidikan Anak Berbasis Fitrah dalam Perspektif Alqur'an, Jurnal Mumtaz, Volume 1 No 2 Tabun 2017, 73

5 Penjelasan dari definisa anak sendiri adalah seorang yang belum berada pada tingkat kematangan baik secara jasmani atau fisiknya maupun rohani atau psikisnya, dan begitu gampang terdoktrin dari lingkungan yang ada di sekitarnya. Tiap dari individu anak pada hakikatnya memerlukan seseorang yang mampu membimbing dan mengarahkan kemampuan dan juga perilakunya, sehingga mampu memberikan perubahan serta berproses secara baik sebagaimana mestinya. Oleh karena itu, menjadi suatu keharusan terhadap diri anak untuk memperoleh dan menempuh proses pendidikan yang berlandaskan pada nilai-nilai ke-Islaman. Kemampuankemampuan yang telah dibawa oleh anak sejak mereka lahir, akan sangart erat berorientasi pada perubahan serta berhubungan erat dengan pengarahan dan pengasuhan dari orangtuanya. Lihat Nur Chasanah, Pendidikan Anak Berbasi Islam di HEbAT Community,. Tesis Pascasarjanan Pendidikan Agama Islam UIN Maulana Malik Ibrahim tahun 2018, 15 
yang layak, pengetahuan, atau materi-materi belajar semata. Penguatan dan penanaman nilai-nilai yang membimbing anak-anak selalu berada di jalan kebaikan, membentuk pribadi yang berkarakter religius, dan mampu melahirkan penerus yang selalu menjadikan Alqur'an dan Hadist sebagai pedoman yang diutamakan, dan itu tak kalah penting ketimbang kebutuhan-kebutuhan yang lainnya.

Setiap anak memiliki keberagaman potensi dan keunikan tersendiri, namun apabila kita coba mengamati fenomena yang terjadi dalam proses pendidikan yang sedang berlangsung sekarang ini masih berfokus pada persamaan dan standarisasi yang berimbas pada hilangnya kepedulian terhadap potensi, minat, serta bakat individu dengan keberagaman dan keunikannya. Belum lagi pembicaraan terkait masih lemahnya kemampuan pendidik dalam mengembangkan pembelajaran-pembelajaran yang inovatif pada setiap proses pembelajaran. Menyalurkan pengetahuan lewat pendidikan itu bukan suatu perihal yang bisa dilakukan secara cepat, hal itu karena pendidikan tak bisa di analogikan seperti mie instan yang siap saji dan bisa dikonsumsi saat itu juga. Banyak hal yang perlu di pelajari dan di pahami, banyak perencanaan yang harus di siapkan, menganalisis kebutuhan yang tidak hanya pada satu sisi penglihatan, serta proses implementasi yang tidak mengikis nilai-nilai fitrah yang utuh pada setiap individu.

Ada beberapa problematika yang muncul pada dunia pendidikan, di antaranya: peningkatan tindak kekerasan yang menghancurkan masa depan generasi muda, perkataan-perkataan yang memiliki kecenderungan menyakiti, teman yang memiliki pengaruh kuat ketimbang orang tua dan pendidik, perilaku seks menyimpang, penggunaan obat terlarang, perilaku moral yang mengalami degradasi, berkurangnya rasa hormat kepada guru dan orang tua, mudah terprovokasi terhadap pengrusakan fasilitas public, melunturnya muatan nilai-nilai kejujuran, serta begitu banyak lahirnya generasi yang 
mudah memiliki kecurigaan, saling membenci satu sama lain yang berdampak pada permusuhan kepada sesama. ${ }^{6}$

Merujuk pada penjelasan dan kegelisahan yang dituliskan di atas, penulis mencoba ingin menghadirkan kembali bagaimana hakikat dari fitrah manusia yang seyogyanya merupakan anugerah dari Allah dan harus dimaksimalkan oleh manusia itu sendiri melalui proses pendidikan, serta interpretasi dan konsep pendidikan anak dalam Islam yang seharusnya selalu menjadi tuntunan para orang tua dan pendidik dalam upaya melahirkan generasi terbaik yang berlandaskan pada Alqur'an dan Hadist tanpa harus melakukan pengecualian pada fitrah itu sendiri. Tulisan ini akan merujuk kepada beberapa sumber relevan yang di anggap memiliki kapasitas keilmuan yang tepat dengan tema tulisan serta masih sangat berkaitan dengan kondisi pendidikan yang ada dan sedang berlangsung sekarang.

\section{METODOLOGI PENELITIAN}

Pada tulisan ini, jenis penelitian yang akan di gunakan adalah jenis penelitian kepustakaan atau yang biasa di kenal dengan penelitian Library Research. Penelitian ini yakni suatu jenis penelitian dengan suatu ciri khas identik dengan mengumpulkan suatu data berbasis kepustakaan, membaca, menuliskan, maupun mengelola bahan penelitian. ${ }^{7}$ Penelitian kepustakaan akan banyak memfokuskan pada membaca dan memahami literatur-literatur yang terkait dengan penelitian yang akan di lakukan. Selain itu peneliti memiliki tuntutan untuk kritis dan optimal dalam mengelola data yang sudah di temukan, sehingga berorientasi pada hasil yang juga tak kalah luar biasa ketika proses pemaparan dalam bentuk tekstual maupun kontekstual. Sumber primer dalam tulisan ini merujuk pada buku Membangun Kreatifitas Anak secara Islam Karya Maemunah Hasan dan buku Fitrah Based

6 Musfiatul Muniroh, Fitrah Based Education: Implementasi Manajemen Pendidikan Berbasis Fitrah di TK Adzkia Banjarnegara, Manageria: Jurnal Manajemen Pendidikan Islam Volume 4 No 2 Tabun 2019, hlm. 248. Lihat juga Harry Santosa, Fitrah Based Education, Bekasi: Yayasan Cahaya Mutiara Timur, 2017, 54

7 Mestika Zed, Metode Penelitian Kepustakaan, Jakarta: Yayasan Obor Indonesia, 2008, 3 
Education Karya Ustadz Harry Santosa. Sedangkan untuk sumber sekunder dalam tulisan ini merujuk kepada beberapa jurnal di antaranya tulisan dari Toni Pransiskan, Konsepsi Fitrah Manusia dalam Perspektif Islam dan Implikasinya dalam Pendidikan Islam Kontemporer, Jurnal Ilmiah DIDAKTIKA Volume 17 No 1 Tahun 2016 dan Nur Chasanah, Pendidikan Anak Berbasis Islam di Hebat Community: Studi Kasus Fitrah Based Education di Hebat Community Cabang Malang Jawa Timur , Tesis UIN Malang Tahun 2018.

\section{HASIL dan PEMBAHASAN}

\section{Fitrah Manusia: Suatu Tinjauan Teoritis}

Manusia merupakan subyek sekaligus obyek dari pendidikan. Dalam proses terlahirnya manusi di bumi yang di iringi dengan pembawaannya seperti cipta, rasa, dan karsa. Semua pembawaan dari manusia itu sangat relevan dengan pembentukan pribadi manusia dalam kebutuhannya melaksanakan proses-proses perjalanan dalam kehidupan.

Merujuk pada salah satu hadist, sudah menyampaikan pada $\mathrm{Al}$ Qa'nabiy, dari malik dari abi al-Zina, dari al A'raj, dari abu hurairah berkata:

Rasulullah telah bersabda bahwa seorang bayke dunia ini melainkan ia berada dalam kesucian (fitrah). Kemudian kedua orang tuanyalah yang akan membuatnya menjadi Yahudi dan Nasrani, sebagaimana binatang melahirkan anaknya dalam keadaan sempurna, adakah kamu merasa kekurangan padanya. ${ }^{8}$

Sebagaimana hadist di atas, apabila coba kita pahami secara seksama, dapat menemukan suatu pemahaman yaitu pandanga awal pada potensi manusia berawal dari ingin tahu bagaimana prosesi kehadiran manusia yang terdiri dari unsur lahiriah dan juga batiniah. Unsur batin terdiri dari seperangkat potensi awal yang itulah dinamakan dengan fitrah, yang mana menurut pandangan ilmu psikologi disebut dengan personalitas, dan biasa juga disebut dalam bahasa psikologi behaviorisme yakni propotence reflexces yang dapat diartikan sebagai potensi awal dengan nilai alamiahnya yang secara

8 http://digilib.uinsby.ac.id Fitrah Anak dalam Tinjauan Hadist, di akses pada tanggal 27 September 2021 
langsung mampu tumbuh dan berkembang. ${ }^{9}$ Fitrah yang Allah berikan untuk manusia adalah berupa potensi serta kreatifitas yang mampu di bangun, serta dapat memungkinkan untuk mengalami perubahan serta mengalami peningkatan. ${ }^{10}$

Istilah "fitrah"11 dalam Alqur'an terdapat dalam Surah Al-Rum ayat 30. Kata fitrah tersebut berasal dari kata fatara, yafturu, fatran. Apabila merunut dari asal kata dan bentuk musytaq-nya, Alqur'an menyebutkan sebanyak 19 kali. ${ }^{12}$ Sementara pemaknaan fitrah secara bahasa dapat diartikan sebagai penciptaan sesuatu, seperti Khalaqallabus samawati wal ard (Allah telah menciptakan langit dan bumi). Contoh lain terdapat pada surah al'Alaq ayat 2 yaitu Khalaqal insan min 'alaq (dia Allah telah menciptakan manusia dari segumpal darah). Dengan begitu, pada tiap penggal ayat yang memakai istilah kbalaqa menisbatkan pelakunya kepada Allah, dalam artian hanya Allah yang bisa menciptakan tiap-tiap dari sesuatu yang tidak mempunyai bahan mentah pada dasarnya. ${ }^{13}$

Dalam penjelasan yang lain, fitrah di artikan sebagai alat potensial dan kemampuan-kemampuan dasar yang dapat dikembangkan dalam kehidupan nyata. Setiap manusia diberi kelengkapan potensi dalam bentuk akal, bakat, imajinasi, ataupun ide atau gagasan. Potensi tersebut dapat membawa manusia pada suatu

9 Chalidjah Hasan, Dimensi-Dimensi Psikologi Islam, Surabaya: Al-Ikhlas, 1994, 35

10 Maimunah Hasan, Membangun Kreatiftias Anak Secara Islam, Yogyakarta: Bintang Cemerlang, 2002., 9

11 Dalam tafsir al-Azhar Buya Hamka menafsirkan fitrah sebagai rasa asli murni yang terdapat di dalam jiwa manusia dan belum sama sekali terkontaminasi dari pihak lain, yakni suatu pengakuan akan adanya kuasa tertinggi di alam ini, yang maha Kuasa, Perkasa, maha Raya, penuh kasih saying, indah sekaligu elok.11 Buya hamka juga mengakui adanya campur tangan dari pihak lain yang akan memberikan pengaruh pada fitrah diri manusia. Pengaruh tersebut tidak hanya dating dari orang tua, tapi orang lain yang memiliki keseharian dengan orang tersebut juga akan membawa pengaruh padanya.apabila pengaruh tersebut merupakan sesuatu yang tidak baik, akan sangat mungkin manusia keluar dari fitrahnya.

12 Muhammad Fuad Abdul Baqi, al-Mu'jam al-Mufahrasa li Alfaz al-Qur'an al Karim, Beirut: Dar Ibya al Turas al-'Arabi, hlm. 522-533. Lihat juga Mujahid, Konsep Fitrah dalam Islam dan Implikasinya Terhadap Pendidikan Islam, Jurnal Pendidikan Agama Islam Volume 2 No. 1 Tabun 2005, 25

13 Mujahid, Konsep Fitrah dalam Islam dan Implikasinya Terhadap Pendidikan Islam, Jurnal Pendidikan Agama Islam Volume 2 No. 1 Tabun 2005, 25 
kesempatan dalam menguasai dan mengembangkan ilmu pengetahuan sert teknologi serta menjadikannya makhluk yang berbudaya. ${ }^{14}$ Berikut ini ada beberapa interpretasi dari pemaknaan fitrah: ${ }^{15}$

1. Fitrah artinya suci (Thubr). Fitrah merupakan kesucian jasmani dan rohani. Dan apabila merujuk pada konteks pendidikan, kesucian merupakan sucinya seorang manusia dari dosa waris.

2. Fitrah artinya Islam. Abu hurairah berpendapat yang diartikan dengan fitrah merupakan agama. Dengan begitu, anak kecil yang meninggal dunia akan masuk surga, dikarenakan terlahir dengan dienul Islam meskipun terlahir dari keluarga yang bukan orang Islam.

3. Fitrah adalah mempercayai ke-Esa an Allah. Manusia terlahir dengan membawa konsep tauhid, atau setidaknya ia memiliki suatu kecenderungan dalam hal mempercayai Tuhan dan akan berusaha menuju ketauhidan tersebut.

4. Fitrah merupakan kemurnian. Manusia terlahir pada sifat-sifat yang beragam, salah satu dari sifat tersebut adalah keihklasan terhadap pelaksanaan setiap kegiatan.

5. Fitrah merupakan suatu keadaan melahirkan manusia yang memiliki orientasi terhadap hal yang disebut dapat menerima suatu kebenaran.

Potensi dasar tersebut merupakan sesuatu yang masih bersifat mentah, atau bisa dikatakan sebagai sesuatu yang tertidur dan berada dalam diri manusia. Apabila potensi tersebut tak kunjung di sadari atau tanpa berusaha menyadari, akan menjadi sesuatu yang stagnan alias tidak berkembang. Oleh karenanya, tak bisa mengabaikan peran serta orang lain sebagai upaya terhadap pengembangan potensi tersebut. Hal tersebut dapat kita lihat dalam Alqur'an Surat Al-Ruum ayat 30, yaitu:

14 Jalaludin, Teologi Pendidikan, Jakarta: Raja Grafindo, 2001, 14

15 Toni Pransiskan, Konsepsi Fitrah Manusia dalam Perspektif Islam dan Implikasinya dalam Pendidikan Islam Kontemporer, Jurnal Ilmiah DIDAKTIKA Volume 17 No 1 Tabun 2016, 6 


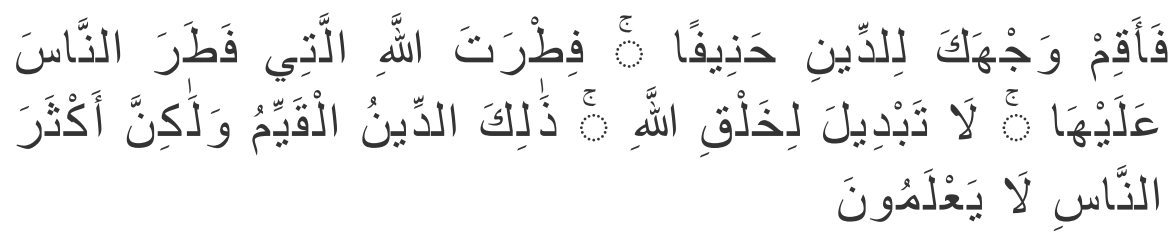

Maka hadapkanlah wajahmu dengan lurus kepada agama Allah; (tetaplah atas) fitrah Allah yang telah menciptakan manusia menurut fitrah itu. Tidak ada peubahan pada fitrah Allah. (Itulah) agama yang lurus; tetapi kebanyakan manusia tidak mengetahui,

Dalam konsep Fitrah Based Education yang ditulis Harry Santosa dan para sahabat, serta diabadikan dalam bentuk buku yang berjudul Fitrah Based Education: Sebuah Model Pendidikan Peradaban Bagi Generasi Peradabam Menuju Peran Peradaban, potensi pada anak terbagi dalam delapan jenis yaitu: (a) potensi $\operatorname{keimanan}^{16}$; (b)potensi belajar dan bernalar ${ }^{17}$; (c) potensi bakat ${ }^{18}$; (d) potensi seksualitas ${ }^{19}$; (e)

16 Tiap-tiap anak terlahir pada suatu kondisi telah membawa fitrah keimanan, selain itu setiap manusia ketika lahir dan berada dalam kandungan pernah bersaksi bahwa Allah sebagai Rabb (khaliqan, raziqan, malikan). Tiada seorangpun anak yang tak memiliki kecintaan terhadap Tuhan serta kebenaran kecuali di simpangkan dan di kubur oleh suatu proses yang namanya pendidikan yang keliru dan terburu-buru. Lihat Nur Chasanah, Pendidikan Anak Berbasis Islam di HEbAT Community: Studi Kasus Fitrah Based Education di HEbAT Community Cabang Malang Jawa Timur, Tesis UIN Malang Tahun 2018, 33

17 Tiap-tiap dari anak tidak lain merupakan pribadi yang haus akan pengetahuan dengan ambisi yang kuat dan pantang menyerah, menjadi kemungkinan yang begitu kecil apabila ada anak yang tidak memiliki keinginan untuk belajar. . Lihat Nur Chasanah, Pendidikan Anak Berbasis.., 33

18 Tiap-tiap anak merupakan sesuatu dengan kelebihan dan keurangannya masing-masing, setiap dari mereka mempunya karakter ataupun fitrah yang special dan itu adalah kodrat yang dimilikinya, dan itu akan menuntunnya pada peran nyata dalam kehidupan. Lihat Thomas Amstrong, Multiple Intelligence in The Classroom, Virginia: ASCD, 2009, hlm. 15. Lihat Juga Lihat Nur Chasanah, Pendidikan Anak Berbasis.., 33

19 Tiap-tiap anak terlahir dengan memiliki status pembeda sebagai laki-laki dan wanita. Bagi manusia, perbedaan status gender tersebut akan mengalami proses perubahan menuju keinginan terhadap seksualitasnya. Untuk wanita juga memiliki peranan keperempuan serta keibuan sejati. Begitu juga dengan jenis kelamin laki-laki, akan memiliki peran keayahan yang sejati. Lihat Nur Chasanah, Pendidikan Anak Berbasis.., 34 
potensi estetika dan bahasa ${ }^{20}$; (f) potensi individualitas dan sosialitas; (g) fitrah jasmani, serta (h) fitrah perkembangan. Beragam jenis fitrah tersebut merupakan objek kajian dalam merancang pendidikan berbasis fitrah. $^{21}$

Esensi yang dapat kita pahami terkait fitrah manusia yang sudah merujuk pada beberapa sumber literatur adalah bahwasanya fitrah manusia itu merupakan suatu kemampuan yang di miliki manusia, dan itu sudah di bawa sejak mereka lahir. Hanya saja fitrah yang di bawa sejak lahir tersebut terkadang terlambat untuk di sadari atau justru tidak sama sekali. Potensi yang seharusnya mampu untuk dikembangkan, justru bergeser pada penguburan potensi yang disebabkan oleh beragam faktor baik itu eksternal maupun internal dari individu itu sendiri.

\section{Pendidikan Anak dalam Pandangan Islam}

Pendidikan tak semata-mata selalu memprioritaskan kemampuan kognitif agar bisa di terima di kehidupan bermasyarakat. Potensi peserta didik sudah seyogyanya dikembangkan oleh setiap pendidikan sebagai upaya melahirkan generasi-generasi emas seperti yang diharapkan. Pendidikan merupakan suatu langkah dalam mewujudkan perubahan pada suatu individu dari hal yang tidak dia ketahui menuju suatu titik dimana individu tersebut mendapatkan kesadaran kritis pada semua hal yang ditemukan pada diri dan lingkungannya. Pendidikan seyogyanya mampu menjadi motor penggerak dalam upaya mengembangkan serta mengoptimalkan semua

20 Tiap-tiap anak mempunyai "sense of aesthetics" nilai estetika serta mengagumi keindahan dan kedamaian, apresiasi dan ekspresi terhadap estetika yang hadir pada bentuk seni, sastra, serta arsitek. Nilai estetika mempunyai tingkatan dari panca indra, khayalan, penalaran, dan batiniah yang berorientasi kepada Tuhan. Tiaptiap anak dibekali potensi serta di bekali kemampuan untuk mengekspresikan keindahan.. Lihat Nur Chasanah, Pendidikan Anak Berbasis.., 34

21 Muksal Mina Putra, dkk, Menumbuhkan Fitrah Keimanan (Kajian Konsep Fitrah Based Education), Zuriab: Jurnal Pendidikan Islam Anak Usia Dini Volume 1 No 1 Tabun 2020, 32 
potensi siswa supaya bisa bersaing secara kompetitif dalam tiap levelnya. ${ }^{22}$

Sementara itu, yang diartikan terhadap pengertian anak ${ }^{23}$ adalah individu yang belum menginjak pada tahapan kematangan, baik secara jasmani maupun rohani dan begitu cepat mendapatkan pengaruh dari lingkungan dan keadaan sekitarnya. Tiap anak pada hakikatnya memerlukan penuntun yang mampu mengarahkan serta mengembangkan kemampuan dan juga perilakunya, sehingga nantinya bisa mencapai suatu perubahan yang lebih baik. Oleh karena itu, sudah seharusnya setiap anak berhak mendapatkan pendidikan yang berlandaskan pada ke-Islaman. ${ }^{24}$

Memperhatikan penggalan-penggalan ayat Alqur'an yang memiliki relevansi terhadap pendidikan anak, terdapat 2 bentuk istilah yang dipakai dalam menyebutkan kata anak, yakni al aulad serta al banun. Bentuk kata tersebut seringkali dihubungkan pada suatu pemaknaan anak secara pesimistis, dengan begitu anak perlu mendapat perhatian yang khusus. ${ }^{25}$ Seperti yang termuat pada Alqur'an surat AtTaubah ayat 55, surat Al-Anfal ayat 28, serta surat Saba' ayat 37, yakni:

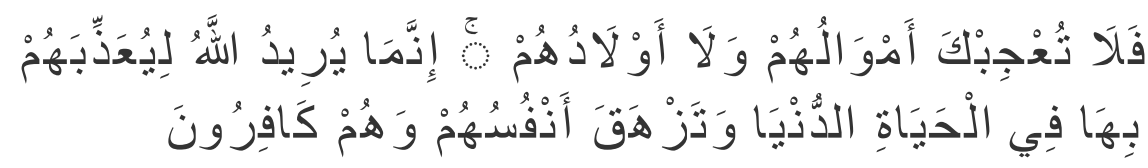

Maka janganlah harta benda dan anak-anak mereka menarik hatimu. Sesungguhnya Allah menghendaki dengan (memberi) harta benda dan anakanak itu untuk menyiksa mereka dalam kehidupan di dunia dan kelak akan melayang nyawa mereka, sedang mereka dalam keadaan kafir.

22 Agus Riyan Oktori, Urgensi Pendidikan Humanis Religius pada Pendidikan Dasar Islam, Jurnal AR-RLAYAH: Jurnal Pendidikan Dasar Volume 1 No 3 Tabun 2019, 180

23 Kata "anak" dalam ungkapan Alqur'an disebutkan dengan istilah al-athfal dengan pengertian anak mulai lahir sampai usia baligh, seperti yang tertera dalam ayat Alqur'an surah An-Nur ayat 59 yang artinya: "dan apabila anak-anakmu telab sampai umur dewasa, mak hendaklah mereka juga meminta izin, seperti orang-orang yang lebih dewasa meminta izin. Demikian Allab menjelaskan ayat-ayatnya kepadamu. Allab Maba Mengetabui, Maha Bijaksana."

24 Lihat Nur Chasanah, Pendidikan Anak Berbasis.., 15

25 Miftahul Huda, dan M. Idris, Nalar Pendidikan Anak, Yogyakarta: ARRUZZ MEDIA, 2008, 76 


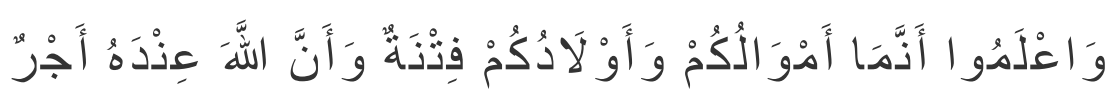

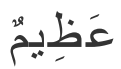

Dan ketahuilah, bahwa hartamu dan anak-anakmu itu hanyalah sebagai cobaan dan sesungguhnya di sisi Allah-lah pahala yang besar.

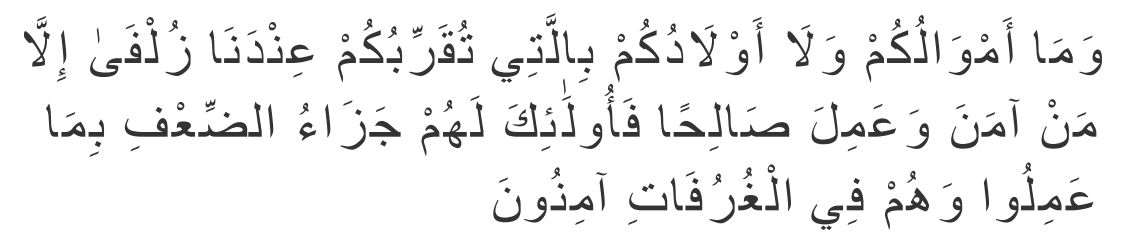

Dan sekali-kali bukanlah harta dan bukan (pula) anak-anak kamu yang mendekatkan kamu kepada Kami sedikitpun; tetapi orang-orang yang beriman dan mengerjakan amal-amal (saleh, mereka itulah yang memperoleh balasan yang berlipat ganda disebabkan apa yang telah mereka kerjakan; dan mereka aman sentosa di tempat-tempat yang tinggi (dalam surga).

Ayat-ayat di atas merupakan rujukan untuk mencurahkan tenaga serta pikiran dalam upaya melakukan perbaikan anak lewat proses pendidikan, sehingga mereka mampu menjadi wasilah untuk mendekatkan diri kepada Allah, buka justru merepotkan orang tua, keluarga, dan lingkungan masyarakat. Sementara itu, istilah al-banun memiliki arti suatu pemahaman terhadap anak secara optimis, sehingga memberikan berdampak pada yang namanya kebanggaan dan kesejukan khusus di dalam hati. ${ }^{26}$ Berikut ini beberapa ayat yang membahas hal tersebut:

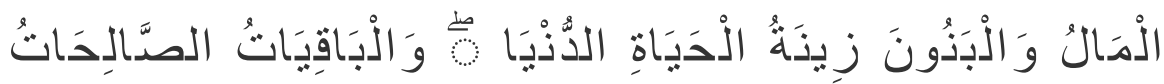

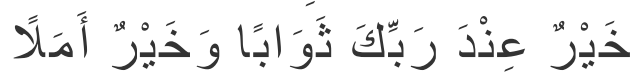

Harta dan anak-anak adalah perhiasan kehidupan dunia tetapi amalan-amalan yang kekal lagi saleh adalah lebih baik pahalanya di sisi Tuhanmu serta lebih baik untuk menjadi harapan.( Alquran QS. Al-Kahfi ayat 46). 


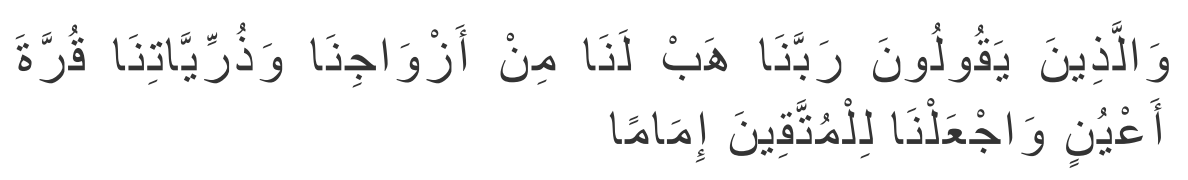

Dan orang orang yang berkata: "Ya Tuhan kami, anugrahkanlah kepada kami isteri-isteri kami dan keturunan kami sebagai penyenang hati (kami), dan jadikanlah kami imam bagi orang-orang yang bertakwa. (Alquran QS. Al-Furqan ayat 74).

Oleh karena itu, anak mampu menjadi harapan dan impian yang menyenangkan apabila anak diberikan pendidikan yang baik, dan justru akan menjadi suatu masalah di kemudian hari apabila tidak mendapatkan pendidikan. Itulah sesuatu yang bisa ditimbulkan, yakni memiliki harapan ataupun tanpa harapan. Hal tersebut akan bermuara terhadap suatu pemahaman yang cukup kompleks. Yang jelas, pada intinya hakikat dari manusia yang dilahirkan dengan fitrah untuk dapat di didik, mampu mendidik, sekaligus melakukan dan mendapatkan keduanya. ${ }^{27}$

Kesimpulannya adalah anak merupakan anugerah yang begitu luar biasa diberikan oleh Allah, dan untuk melahirkan generasi-generasi yang juga tak kalah luar biasa harus melalui proses atau tahapan yang tidak sebentar dan melibatkan banyak faktor. Dalam proses tersebut mampu memperlihatkan setiap potensi yang dimiliki oleh anak, salah satunya proses dalam pendidikan. Proses tersebut bisa di katakana sebagai proses membentuk, mengarahkan, menguatkan, serta memaksimalkan kemampuan setiap anaknya. Agama Islam mengajarkan hal-hal yang begitu luar biasa dalam menuntun seseorang untuk menjadi lebih baik berdasarkan potensi yang dimiliki. Oleh karena itu, sudah seyogyanya dalam proses menanamkan nilai-nilai kebaikan pada setiap diri anak dalam hal pendidikan harus merujuk kepada yang sudah dianjurkan oleh Islam, bukan justru menggeser nilai-nilai baik dan melakukan penguburan karakter anak yang bertentangan dengan ajaran agama Islam itu sendiri. 


\section{Pendidikan Anak Berbasis Fitrah}

Pendidikan seharusnya memiliki ciri-ciri sebagai berikut: (a) proses pembelajara yang berbasis student centered; (b) harus inovatif dan luwes; (c) selalu berlandaskan pada keanekaragaman setiap anak, dan kecerdasan yang lebih dari satu; (d) selalu memberi dukungan terhadap pembiasaan untuk berproses; (e) proses yang menumbuh kembangkan kreatifitas dan rasa tanggung jawab; (f) membangun rasa toleransi; (g) biaya pendidikan yang merakyat; dan (h) relevan terhadap kebutuhan pendidikan. ${ }^{28}$

Krisis kemanusiaan di iringi dengan mulai munculnya fenomena melemahnya bakat dan akhlak, krisis terhadap alam yang dapat di lihat dari berkurang bahkan hilangnya berbagai macam keanekaragaman hayati, budaya kearifan dan kemulai bangsa yang semakin tergerus, memudarnya muatan nilai-nilai keagaamaan yang berdampak pada kaburnya sesuatu terhadap nilai spiritual dan moral. Kesalah pahaman dalam proses pendidikan telah mewariskan beragam problematika yang sampai hari ini masih terus berlangsung, dan sangat perlu mendapatkan perhatian lebih agar tidak berdampak pada gejalagejala yang lebih rumit lagi. Menjadi sesuatu yang begitu penting dalam Islam, memberikan tempat pada setiap manusia untuk memperoleh yang namanya pendidikan. ${ }^{29}$

Pendidikan berbasis fitrah sebenarnya begitu sederhana. Kita sebagai pendidik hanya perlu mengedepankan proses pendidikan yang senatural mungkin, dan sesuai dengan fitrah serta menjalaninya dengan menyesuaikan pada proses perkembangan manusia. Tujuannya sendiri yaitu supaya tiap-tiap dari ini berkembang berdasarkan potensinya, memiliki tugas sebagai hamba maupun pemimpin yang jelas arahnya berdasarkan fitrah bakat yang dimilikinya, memiliki kompetensi yang inovatidf untuk mensejahterakan bumi berdasarkan fitrah belajarnya,

28 Daniel Mohammad Rosyid, Sekolah Rumah Strategi Deschooling dalam Peningkatan Kinerja Sistem Pendidikan Nasional, 2017. Di akses pada 01 Oktober 2021

29 Aas Siti Sholichah, Konsepsi Pendidikan Anak Berbasis Fitrah dalam Perspektif Alqur'an, Jurnal Mumtaz Volume 1 Nomor 2 Tahun 2017, 72 
serta memiliki akhlak mulia berdasarkan fitrah keimanannya. Berikut ini akan di jabarkan dasar dari pendidikan fitrah. ${ }^{30}$

1. Hakikat dari pendidikan fitrah yaitu mengayomi dan tidak mengatur. Prinsip dalam pendidikan berbasis fitrah merupakan suatu keyakinan dan sikap optimis bahwasanya tiap anak yang terlahir itu adalah memiliki potensi. Dengan begitu, menjadi suatu kewajiban untuk meyakini bahwa mereka memiliki potensi. Apabila proses pendidikan selalu berorientasi pada pengendalian, intervensi, dan mendominasi, bukan suatu yang tidak mungkin akan merusak potensi fitrah anak tersebut. ${ }^{31}$

2. Esensi dasar dari pendidikan fitrah yaitu membangunkan serta menyadarkan, bukan justru melakukan rekayasa. Memberikan pendidikan tidak hanya menyuapkan, menuangkan, atau lain sebagainya. Sesuatu yang lebih dari itu, yakni menghidupkan dan menguatkan potensi dari setiap anak tersebut. Akan menjadi lebih penting jika anak memiliki gairah terhadap belajar, kecintaan terhadap Alqur'an, dan buku ketimbang menguasai banyak pelajaran yang berorientasi menuntut cepat membaca dan menghafalnya. Keinginan untuk belajar bukan hanya dihadirkan berdasarkan keseringan seseorang dalam memberikan pelajaran, melainkan pada pemberian suatu gagasan yang membuka wawasan serta menginspirasi. Dengan begitu, secara tidak langsung seluruhnya akan menjadi baik jika berkembang dan memiliki keterkaitan terhadap fitrah.

3. Memaksimalkan momentum menjadi sesuatu yang bagus ketimbang memberikan manajemen terstruktur namun kaku. Sesungguhnya Allah merupakan guru terbaik untuk seluruh umat yang ada di muka bumi, dengan segala hal yang telah diberikan oleh Allah, tiap waktunya, tiap harinya semua digariskan bertemu dengan kejadian-kejadian seru dalam setiap

30 Musfiatul Muniroh, Fitrah Based Education: Implementasi Manajemen Pendidikan Berbasis Fitrah di TK Adzkia Banjarnegara, Manageria: Jurnal Manajemen Pendidikan Islam Volume 4 No 2 Tabun 2019, 252

31 Musfiatul Muniroh, Fitrah Based Education: Implementasi Manajemen.., 253 
sendi proses kehidupan. Banyak kejadian yang tidak di sengaja kemudian apabila di amati dengan seksama, akan menjadi minat dari keseriusan dari anak.

4. Merancang program yang kemudian dikerjakan bersama anak sesuai keunikannya.

5. Menyusun program yang berbeda untuk anakhal tersebut tidak lain karena tiap tiap anak adalah "very special limited edition". Kegiatan yang di susun seyogyanya berkaitan dengan potensi anak dan keluarganya.

6. Menyesuaikan dengan proses spertumbuhan anak. Pada bagian yang ini merupakan sesuatu yang sangat penting dan tidak boleh di lakukan secara terburu-buru, kalau di umpamakan sebagai proses menanam tumbuhan, jadi harus sesuai dengan proses dan keperluan dari tumbuhan tersebut. Apabila memberikan air dan nutris yang terlalu berlebihan, justru akan membuat akar menjadi busuk, menempatkan tanaman yang tidak sesuai dengan lahan juga akan membuat gagal panen.

7. Tujuan umum dari pendidikan berbasis fitrah yaitu memberikan kejelasan yakni tiap anak merupakan "right on place". 32

\section{Simpulan}

Allah sudah menurunkan beragam kelebihan pada manusia, terkhusus keberagaman potensi dan keunikan yang memiliki sifat dinamis dalam proses perjalanan perkembangannya. Fitrah manusia yang berupa potensi tersebut memerlukan usaha agar mampu tumbuh dan berkembang sesuai dengan apa yang dimilikinya. Baik atau tidaknya suatu manusia akan turut andil dipengaruhi oleh lingkungan keluarga, lingkungan masyarakat, dan lingkungan pendidikan. Oleh karena itu, sudah sepatutnya proses tumbuh kembang potensi tersebut harus tetap berada pada koridor koridor yang semestinya, agar tidak melahirkan generasi-generasi yang jauh dari harapan, generasi yang tidak mengenali diri, serta generasi yang menidurkan bahkan menguburkan potensinya karena tidak tersentuh dan terbaikan akibat kesalah pahaman dalam proses pendidikan.

32 Musfiatul Muniroh, Fitrah Based Education: Implementasi Manajemen..,hlm. 254 
Bercermin pada konsep pendidikan anak berbasis fitrah ataupun tidak berbasis fitrah, akan begitu terlihat jelas pada tahapan yang akan di lakukan, mulai dari input, output, proses, maupun outcome. Suatu proses yang mengedepan sesuatu berdasarkan potensi anak akan melahirkan generasi-generasi yang memiliki kebanggaan luar biasa terhadap dirinya sendiri terkhusus pribadi anak yang selalu bersikap optimis dan berkemajuan, dan kemampuan tersebut mampu memberikan kontribusi yang luar biasa terhadap perubahan yang akan terjadi di masa yang akan datang. Sementara itu, akan melahirkan generasi sebaliknya apabila suatu proses pendidikan yang hanya fokus pada pengembangan kemampuan kognitif saja, tanpa harus peduli pada kemampuan afektif dan psikomotorik yang dimiliki oleh anak. Pengabaian tersebut justru memutuskan potensi anak untuk mengembangkan kemampuannya yang bisa di katakana tidak maksimal pada potensi kognitif seperti anak-anak yang lainnya.

\section{Daftar Pustaka}

Abdul Baqi Muhammad Fuad, al-Mu'jam al-Mufahrasa li Alfaz alQur'an al Karim, Beirut: Dar Ihya al Turas al-'Arabi

Amstrong, Thomas Multiple Intelligence in The Classroom, Virginia: ASCD, 2009

Chasanah Nur, Pendidikan Anak Berbasis Islam di HEbAT Community: Studi Kasus Fitrah Based Education di HEbAT Community Cabang Malang Jawa Timur, Tesis UIN Malang Tahun 2018

Hasan Chalidjah, Dimensi-Dimensi Psikologi Islam, Surabaya: AlIkhlas, 1994

http://digilib.uinsby.ac.id Fitrah Anak dalam Tinjauan Hadist, di akses pada tanggal 27 September 2021

Jalaludin, Teologi Pendidikan, Jakarta: Raja Grafindo, 2001

Lukis Alam, Perspektif Pendidikan Islam Mengenai Fitrah Manusia, Jurnal Tarbawi Volume 1 No. 2 Tahun 2015

M. Idris Miftahul Huda, dan, Nalar Pendidikan Anak, Yogyakarta: ARRUZZ MEDIA, 2008

Maimunah Hasan, Membangun Kreatiftias Anak Secara Islam, Yogyakarta: Bintang Cemerlang, 2002 
Mina Putra Muksal, dkk, Menumbuhkan Fitrah Keimanan (Kajian Konsep Fitrah Based Education), Zuriah: Jurnal Pendidikan Islam Anak Usia Dini Volume 1 No 1 Tahun 2020

Mualimin, Konsep Fitrah Manusia dan Implikasinya dalam Pendidikan Islam, At-Tadzkiyah: Jurnal Pendidikan Islam Volume 8 No 2 Tahun 2017

Mujahid, Konsep Fitrah dalam Islam dan Implikasinya Terhadap Pendidikan Islam, Jurnal Pendidikan Agama Islam Volume 2 No. 1 Tahun 2005

Muniroh Musfiatul, Fitrah Based Education: Implementasi Manajemen Pendidikan Berbasis Fitrah di TK Adzkia Banjarnegara, Manageria: Jurnal Manajemen Pendidikan Islam Volume 4 No 2 Tahun 2019

Musfiatul Muniroh, Fitrah Based Education: Implementasi Manajemen Pendidikan Berbasis Fitrah di TK Adzkia Banjarnegara, Manageria: Jurnal Manajemen Pendidikan Islam Volume 4 No 2 Tahun 2019

Nata Abuddin, Filsafat Pendidikan Islam, Jakarta: Logos Wacana Ilmu, 1997

Oktori Agus Riyan, Urgensi Pendidikan Humanis Religius pada

Pendidikan Dasar Islam, Jurnal AR-RIAYAH: Jurnal Pendidikan Dasar Volume 1 No 3 Tahun 2019

Pransiskan Toni, Konsepsi Fitrah Manusia dalam Perspektif Islam dan

Implikasinya dalam Pendidikan Islam Kontemporer, Jurnal Ilmiah DIDAKTIKA Volume 17 No 1 Tahun 2016

Rosyid Daniel Mohammad, Sekolah Rumah Strategi Deschooling dalam Peningkatan Kinerja Sistem Pendidikan Nasional, 2017. Di akses pada 01 Oktober 2021

Santosa Harry, Fitrah Based Education, Bekasi: Yayasan Cahaya Mutiara Timur, 2017

Siti Solichah Aas, Konsepsi Pendidikan Anak Berbasis Fitrah dalam Perspektif Alqur'an, Jurnal Mumtaz Volume 1 No 2 Tahun 2017

Yasir Nasution Muhammad, Manusia Menurut Al-Ghazali, Jakarta: Rajawali Press, 1988 
190 | AR:-RIAYAH :Jurnal Pendidikan Dasar Vol. 5, No. 2, 2021

Zed Mestika, Metode Penelitian Kepustakaan, Jakarta: Yayasan Obor Indonesia, 2008 